Check for updates

Cite this: RSC Adv., 2021, 11, 13666

Received 15th December 2020

Accepted 26th March 2021

DOI: $10.1039 /$ dOra10548a

rsc.li/rsc-advances

\section{A facile and efficient route to one-pot synthesis of new cyclophanes using vinamidinium salts $\dagger$}

\author{
Nooshin Golzar, Abdolmohammad Mehranpour (iD)* and Najmeh Nowrouzi (D) \\ In this study, an efficient method for the synthesis of new cyclophanes $(5 a-f, 6 a-g)$ through the \\ condensation of 1,4-phenylenedimethanamine (3) or 2,3,5,6-tetramethylbenzene-1,4-diamine (4) with 2- \\ substituted vinamidiniums $(2 \mathrm{a}-\mathrm{g})$ is described. The cyclophane derivatives are obtained in good to \\ excellent yields in the presence of acetic acid in refluxing acetonitrile after $15 \mathrm{~h}$. The structure of new \\ compounds was validated based on their spectral data $\left({ }^{1} \mathrm{H} N \mathrm{NR},{ }^{13} \mathrm{C} N \mathrm{NR}, \mathrm{R}\right)$ and elemental analysis.
}

\section{Introduction}

The structure of a vast range of macromolecules ${ }^{1}$ confirmed that the design and construction of macrocyclic compounds has been one of the most important reasons for improvement in supramolecular science. A well-known group of macrocyclic compounds are cyclophanes and their particular chemistry has attracted the attention of researchers, recently ${ }^{2}$ and has been broadly discussed within the field of modern supra-molecular chemistry. ${ }^{3,4}$ Cyclophanes ${ }^{5-42}$ are constrained organic molecules consisting of aromatic ring(s) as well as aliphatic unit(s). The aromatic rings support the rigidity of their structure, while the aliphatic unit(s) create bridge(s) between the aromatic rings and cause the flexibility of the whole structure.

Due to their special structure, they are considered as an important class of compounds in "host-guest" chemistry ${ }^{43-47}$ and supramolecular assembly. ${ }^{48-51}$ On the other hand, the clear structure and high strain of cyclophanes has contributed in a large number of applications such as pharmaceuticals, ${ }^{52,53}$

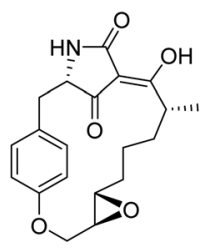

Macrocidin A Herbicide agent

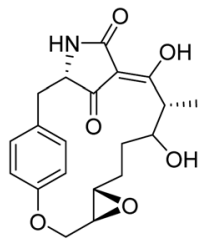

Macrocidin B Herbicide agent

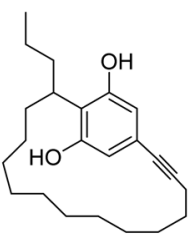

Nostocyclyne A Antimicrobial agent
Fig. 1 Natural products containing the cyclophane skeleton.

Department of Chemistry, Faculty of Sciences, Persian Gulf University, Bushehr, 75169, Iran.E-mail: ammehranpour@hotmail.com

$\dagger$ Electronic supplementary information (ESI) available. See DOI: 10.1039/d0ra10548a asymmetric catalysis ${ }^{54}$ insulating plastics, ${ }^{55}$ organic electronics, ${ }^{56}$ metal capture ${ }^{57,58}$ and supramolecular chemistry. ${ }^{59}$ Besides, since cyclophane structure is the main foundation unit in many biologically active natural products (Fig. 1), ${ }^{60-62}$ their design and application is a special interest of groups working in
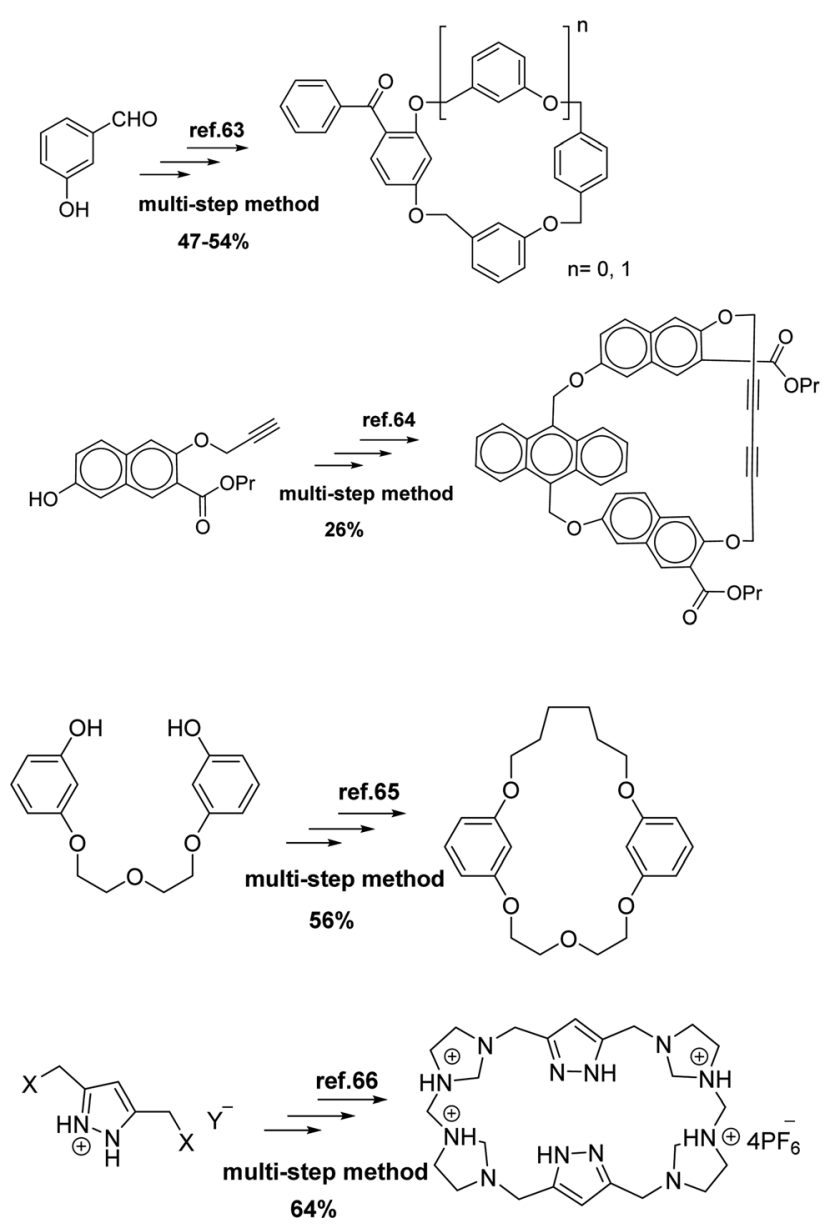

Scheme 1 Reported methods for the synthesis of cyclophanes. 


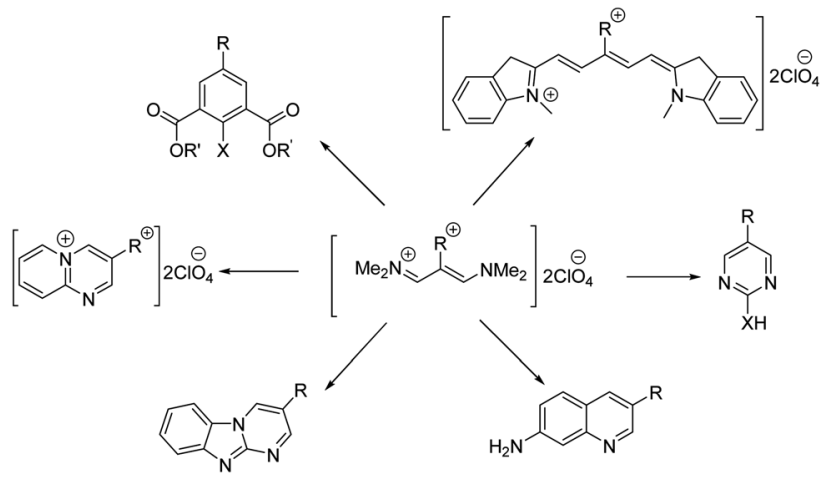

Scheme 2 Application of vinamidinium salts in organic synthetic chemistry.

fields including biological, medicinal and organic chemistry. Moreover, cyclophanes are attractive in the area of theoretical chemistry due to their particular topology and intra-molecular interactions.

So far, several methods have been reported for the synthesis of cyclophanes compounds ${ }^{63-66}$ (Scheme 1). In some instances, cyclophanes are formed in low yields and also with side products. Some procedures require many steps or harsh reaction conditions such as high-pressure, and difficult separation

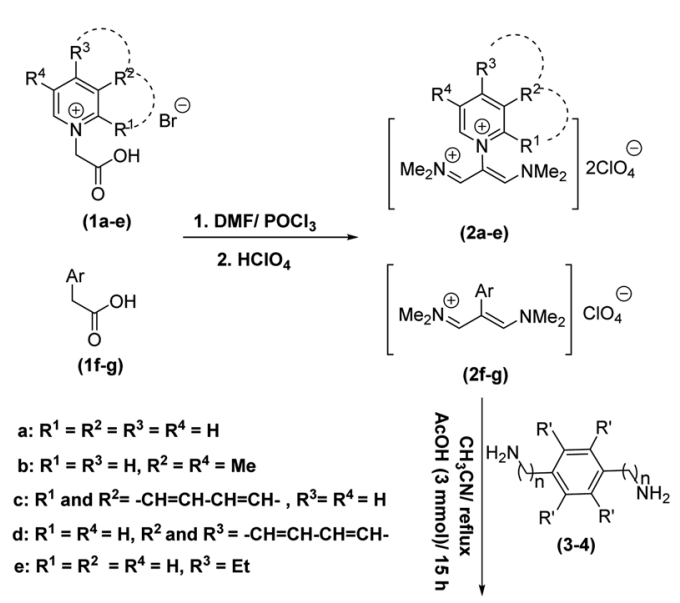

(2f)

(1 mmol)

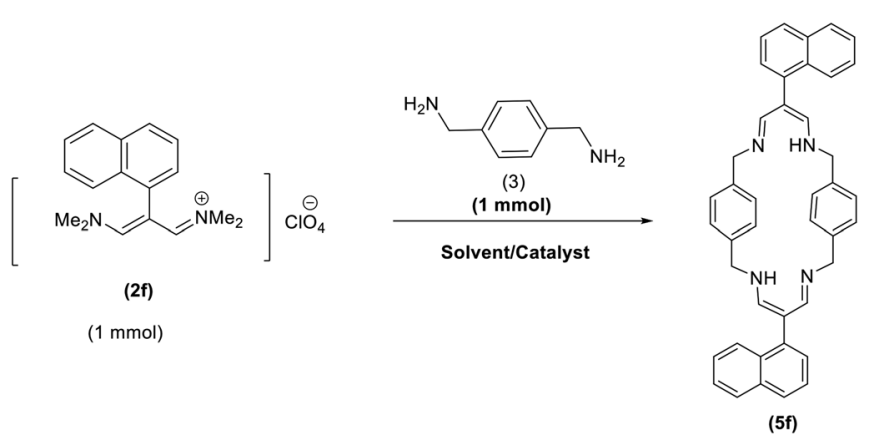

Solvent/Catalyst

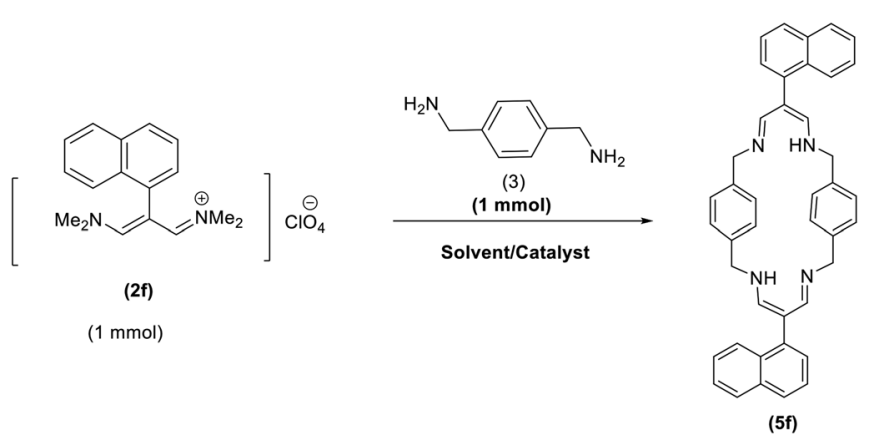

methods. Therefore, designing better routes and improving conditions to achieve cyclophanes is still needed.

Vinamidinium salts are examples of stabilized alkenes by "push-pull" influences between the electron-donating amino group and the electron-withdrawing ammonium group. They can easily undergo condensation reaction with bifunctional nucleophiles to form heterocycles. During past years, our group has been investigated the utilization of vinamidinium salts for the synthesis of heterocyclic compounds ${ }^{67-76}$ (Scheme 2).

\section{Results and discussion}

In continuation of these studies and due to the importance of cyclophanes in different branches of sciences, we decided to investigate the one-pot synthesis of cyclophanes from vinamidinium salts (Scheme 3). To the best of our knowledge, vinamidinium salts have not yet been applied for preparing cyclophanes.

As shown in Scheme 3, the procedure is done in two-step: (i) synthesis of the 2 -substituted vinamidinium salts $(2 \mathbf{a}-\mathbf{g})$ by the Vilsmeier-Arnold formylation of the substituted acetic acids $(\mathbf{1 a}-\mathbf{g})$ as explained in authors previous work; ${ }^{67-76}$ and (ii) synthesis of cyclophane derivatives $(\mathbf{5 a}-\mathbf{f}, \mathbf{6 a}-\mathbf{g})$ by the reaction of 2-substituted vinamidinium salts $(\mathbf{2 a - g})$ with 1,4-

Table 1 Effect of the different reaction parameters on the reaction of 1,4-phenylenedimethanamine (3) with ((E)-N-(3-(dimethylamino)-2(naphthalen-1-yl)allylidene)- $\mathrm{N}$-methylmethanaminium perchlorate (2f))

(5f)

\begin{tabular}{|c|c|c|c|c|}
\hline Entry & Condition & Solvent & Time (h) & Yield $^{a}(\%)$ \\
\hline 1 & AcOH (3 mmol) & EtOH/reflux & 24 & 43 \\
\hline 2 & AcOH $(3 \mathrm{mmol})$ & $\mathrm{MeOH} /$ reflux & 24 & 36 \\
\hline 3 & AcOH (3 mmol) & $\mathrm{CH}_{3} \mathrm{CN} /$ reflux & 15 & 90 \\
\hline 4 & $\mathrm{AcOH}(3 \mathrm{mmol})$ & $\mathrm{CHCl}_{3} /$ reflux & 24 & 35 \\
\hline 5 & $\mathrm{AcOH}(3 \mathrm{mmol})$ & $\mathrm{CH}_{2} \mathrm{Cl}_{2} /$ reflux & 24 & Trace \\
\hline 6 & $\mathrm{AcOH}(3 \mathrm{mmol})$ & Toluene/reflux & 24 & - \\
\hline 7 & AcOH $(3 \mathrm{mmol})$ & $\mathrm{DMF} / 100{ }^{\circ} \mathrm{C}$ & 24 & 45 \\
\hline 8 & $\mathrm{Et}_{3} \mathrm{~N}(3 \mathrm{mmol})$ & $\mathrm{CH}_{3} \mathrm{CN} /$ reflux & 24 & - \\
\hline 9 & i-Pr ${ }_{2} \mathrm{NEt}(3 \mathrm{mmol})$ & $\mathrm{CH}_{3} \mathrm{CN} /$ reflux & 24 & - \\
\hline 10 & - & $\mathrm{CH}_{3} \mathrm{CN} /$ reflux & 24 & - \\
\hline 11 & $\mathrm{AcOH}(4 \mathrm{mmol})$ & $\mathrm{CH}_{3} \mathrm{CN} /$ reflux & 15 & 90 \\
\hline 12 & $\mathrm{AcOH}(2 \mathrm{mmol})$ & $\mathrm{CH}_{3} \mathrm{CN} /$ reflux & 24 & 64 \\
\hline 13 & AcOH (1 mmol) & $\mathrm{CH}_{3} \mathrm{CN} /$ reflux & 24 & 40 \\
\hline
\end{tabular}

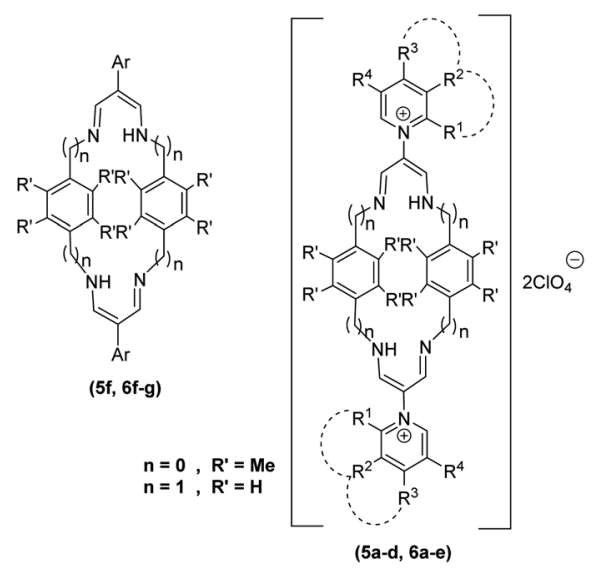

${ }^{a}$ Isolated yield.

Scheme 3 Synthesis of cyclophanes. 
phenylenedimethanamine (3) or 2,3,5,6-tetramethylbenzene1,4-diamine (4) by applying acetic acid in acetonitrile as solvent.

In the first step, vinamidiniums were isolated as the perchlorate salts and used directly without additional purification for the synthesis of cyclophanes.

As illustrated in Scheme 3, the symmetrical vinamidinium salts (2a-g) were able to react with 1,4- phenylenedimethanamine (3) or 2,3,5,6-tetramethylbenzene1,4-diamine (4) in refluxing acetonitrile in the presence of acetic acid for $15 \mathrm{~h}$ to manage the cyclophane derivatives (5a-f, 6ag). To provide the best reaction conditions in second step, the reaction of vinamidinium salt $2 \mathbf{f}$ with 1,4-phenylenedimethanamine (3) was chosen as model reaction and the impacts of solvents and catalysts were investigated. The obtained results

Table 2 The synthesis of cyclophane derivatives from the reaction of 2-substituted vinamidinium salts $(2 \mathrm{a}-\mathrm{g})(1.0 \mathrm{mmol}), 1,4-\mathrm{phenyl}-$ enedimethanamine (3) $(1.0 \mathrm{mmol})$ in the presence of $\mathrm{AcOH}(3.0 \mathrm{mmol})$ in $\mathrm{CH}_{3} \mathrm{CN}(8.0 \mathrm{~mL})$ at reflux conditions

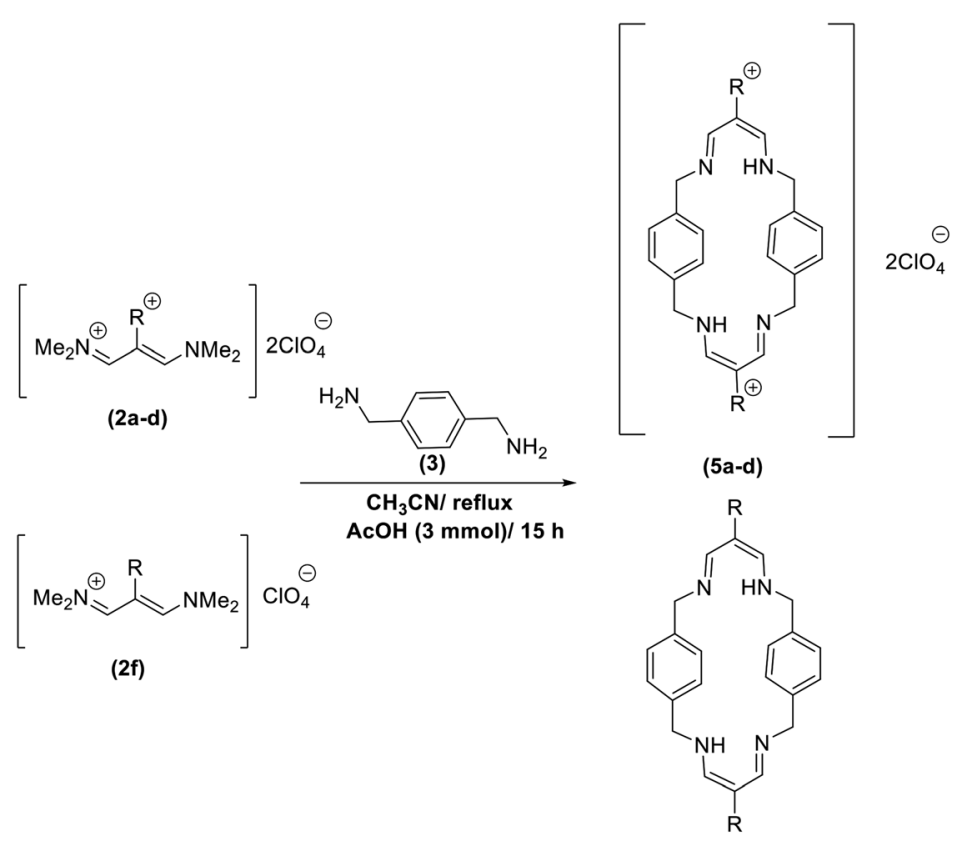

(5f)

${ }^{a}$ Isolated yield. 
are summarized in Table 1. When $\mathrm{EtOH}$ and $\mathrm{MeOH}$ were applied as the solvent and the mixture was subjected to reflux in the presence of $\mathrm{AcOH}$, the desired product, 5f, was achieved in low yields ( $43 \%$ and 36\%, respectively) after $24 \mathrm{~h}$ (Table 1, entries 1 and 2). In a modified protocol, the reaction was carried out in refluxing acetonitrile. In this case, remarkable

Table 3 The synthesis of cyclophane derivatives from the reaction of 2-substituted vinamidinium salts (2a-g) (1.0 mmol), 2,3,5,6-tetramethylbenzene-1,4-diamine (4) $(1.0 \mathrm{mmol})$ in the presence of $\mathrm{AcOH}(3.0 \mathrm{mmol})$ in $\mathrm{CH}_{3} \mathrm{CN}(8.0 \mathrm{~mL})$ at reflux conditions
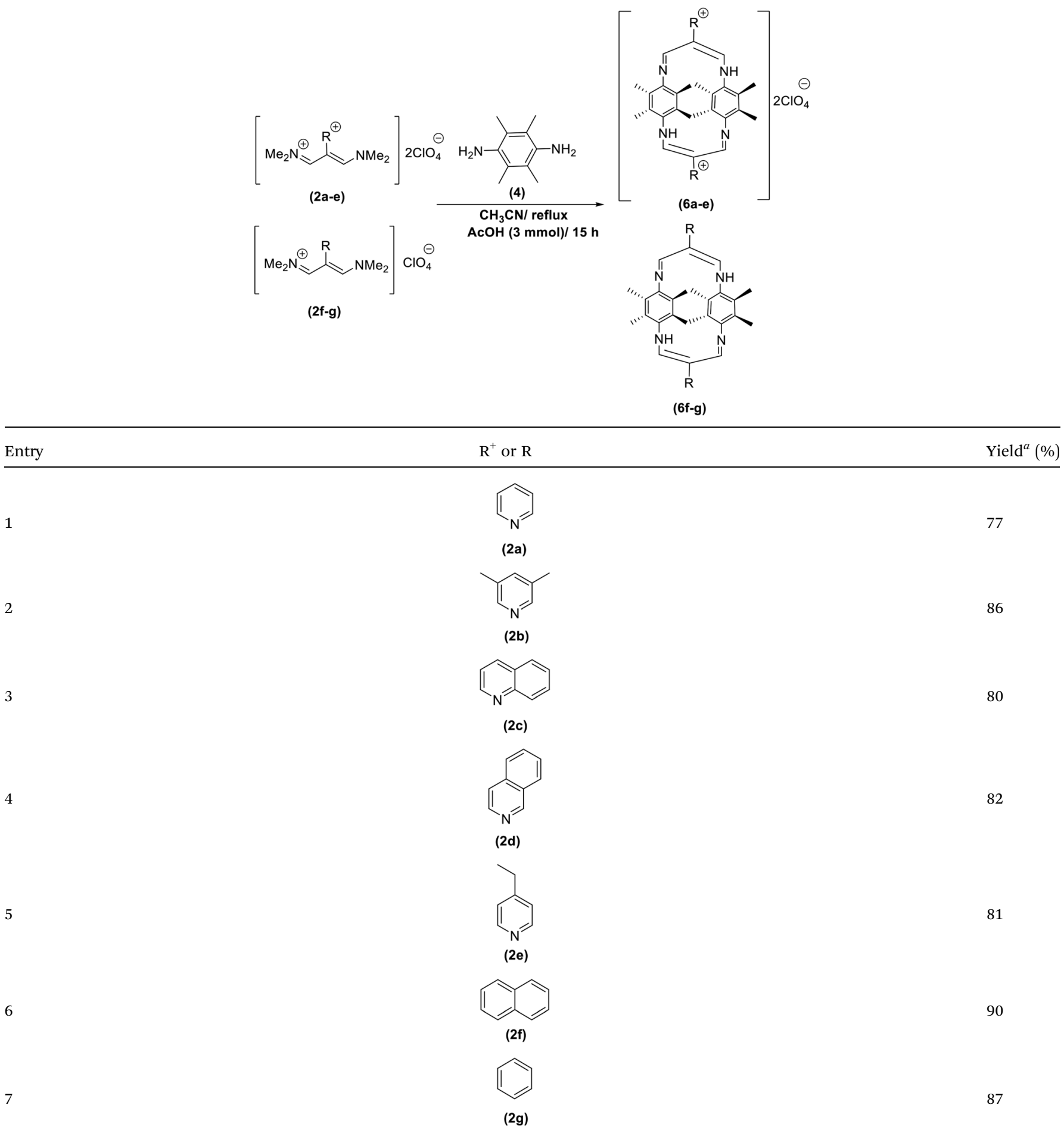

${ }^{a}$ Isolated yield. 
improvement of yield was observed (Table 1, entry 3 ). No better results were obtained when the reaction was carried out in DMF, $\mathrm{CHCl}_{3}, \mathrm{CH}_{2} \mathrm{Cl}_{2}$ or toluene (Table 1, entries 4-7). Therefore, the subsequent reactions were carried out in $\mathrm{CH}_{3} \mathrm{CN}$.

After choosing the solvent, the model reaction was conducted under neutral and basic conditions. As shown in entries 8 and 9 of Table 1, in the presence of basic catalysts such as triethylamine and ethyldiisopropylamine, the desired product 5f, was not achieved. In neutral conditions also, no product was formed (Table 1, entry 10). Increasing the amount of AcOH did not affect the reaction appreciably, while, decreasing the amount of $\mathrm{AcOH}$, resulted the product in lower yield (Table 1, entries 11-13). So, acidic media is critical to the success of the reaction.

We then applied the obtained optimized conditions for the reaction of different vinamidinium salts with 1,4-phenylenedimethanamine (3). The results are listed in Table 2.

The results demonstrated that the variety of vinamidinium salts were successfully employed in this process, affording novel cyclophanes in high yields in suitable reaction times.

After successful application of 1,4-phenylenedimethanamine (3) in cyclophane synthesis, to enhance the generality of

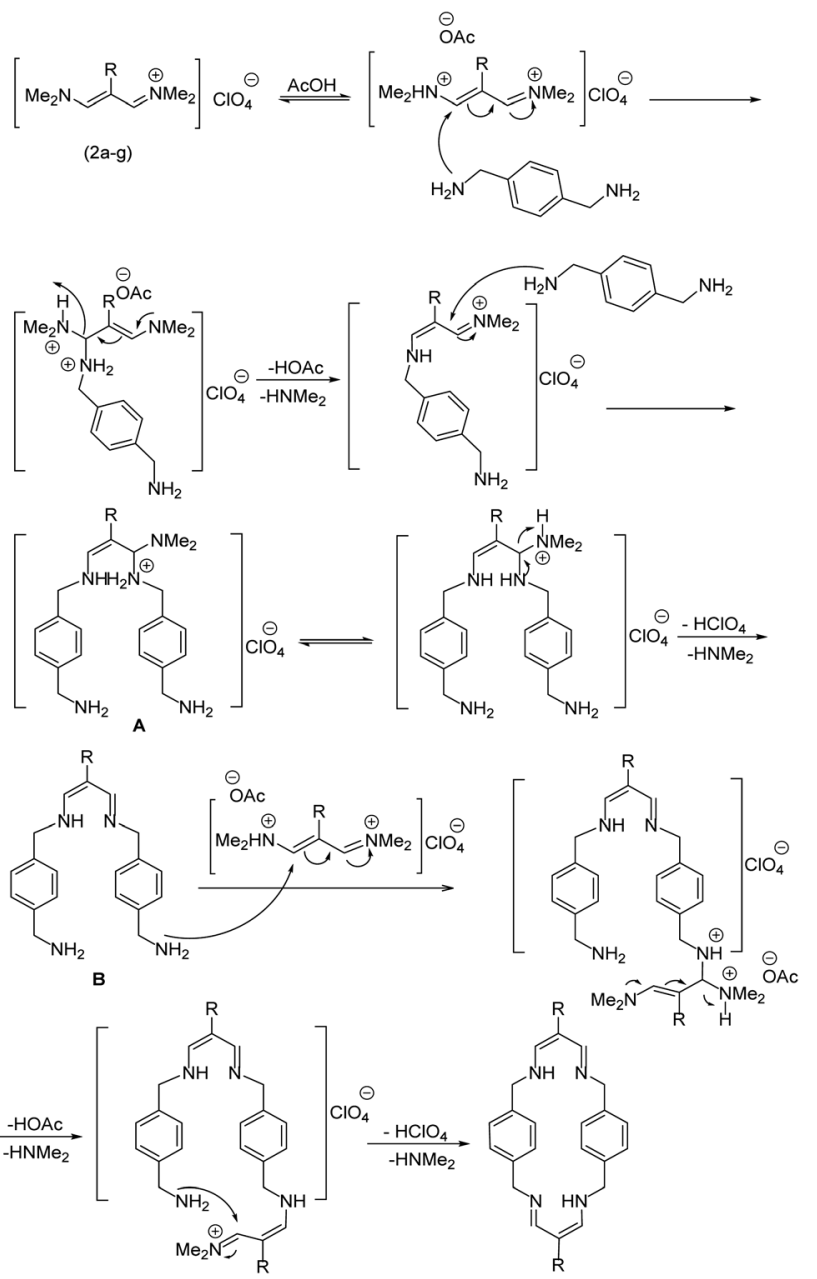

Scheme 4 The proposed mechanism for the synthesis of cyclophanes in the presence of $\mathrm{AcOH}$. the system, we applied 2,3,5,6-tetramethylbenzene-1,4-diamine (4) as bifunctional nucleophile and investigated the formation of new cyclophanes.

2,3,5,6-Tetramethylbenzene-1,4-diamine (4) was also tolerated well in this procedure to give the desired products (Table 3).

According to our previous works and above results, a reasonable mechanism for the synthesis of cyclophane compounds (5a-f, $\mathbf{6 a}-\mathbf{g}$ ) in the presence of $\mathrm{AcOH}$ is illustrated in Scheme 4.

The reaction proposed by the initial attack of the amino group in 1,4-phenylenedimethanamine (3) or 2,3,5,6tetramethylbenzene-1,4-diamine (4) to protonated vinamidinium salt. Then, removal of dimethylamine occurs, followed by the nucleophilic attack of second molecule of amine on the obtained iminium salt to produce intermediate A. The loss of the second dimethylamine molecule produces intermediate $\mathbf{B}$. The reaction of this intermediate with the second molecule of vinamidinium salt, followed by the loss of two dimethylamine molecules and intramolecular nucleophilic cyclization, yields the desired cyclophane.

\section{Conclusion}

In this study, an efficient and applicable protocol has been developed for the synthesis of novel cyclophanes by the reaction of 2-substituted vinamidinium salts with 1,4-phenylenedimethanamine or 2,3,5,6-tetramethylbenzene-1,4-diamine in the presence of acetic acid.

This protocol has several advantages such as: simple and one-step procedure, absence of by-products, inexpensive catalyst, normal atmospheric conditions, high to excellent yields and easy purification of the products. Furthermore, the products are well-known, stable solids and have a long shelf-life when stored in an anhydrous environment.

\section{Experimental section}

General procedure for the synthesis of cyclophane derivatives (5a-f, 6a-g)

To a flame dried one-necked round-bottomed flask equipped with magnetic stirring and reflux condenser, 2-substituted vinamidinium salts (2a-g) $\quad(1.0 \quad \mathrm{mmol})$, 1,4-phenylenedimethanamine (3) or 2,3,5,6-tetramethylbenzene-1,4diamine (4) $(1.0 \mathrm{mmol}), \mathrm{AcOH}(3.0 \mathrm{mmol})$ and $\mathrm{CH}_{3} \mathrm{CN}(8.0$ $\mathrm{mL}$ ) were added. The mixture was allowed to reflux for $15 \mathrm{~h}$ in an oil bath. After completion of the reaction, distilled $\mathrm{H}_{2} \mathrm{O}(20$ $\mathrm{mL}$ ) was added to the mixture. The resulting precipitate was gathered, washed with $\mathrm{Et}_{2} \mathrm{O}(3 \times 3 \mathrm{~mL})$. Finally, the precipitate was washed with 2-propanol $(3 \times 3 \mathrm{~mL})$ and dried under vacuum at $80{ }^{\circ} \mathrm{C}$ to afford the corresponding cyclophanes.

\section{Conflicts of interest}

There are no conflicts of interest to declare. 


\section{Acknowledgements}

The authors thank Persian Gulf University Research Councils for the financial support of this work.

\section{Notes and references}

1 Encyclopedia of supramolecular chemistry, ed. J. L. Atwood and J. W. Steed, Marcel Dekker, New York, 2004.

2 Modern cyclophane chemistry, ed. R. Gleiter and H. Hopf, Wiley-VCH, Weinheim, 2004.

3 J. W. Steed and J. L. Atwood, Supramolecular chemistry, John Wiley \& Sons Ltd, Chichester, England, 2000.

4 F. Diederich, Cyclophanes. Monographs in Supramolecular Chemistry, ed. J. F. Stoddart, The Royal Society of Chemistry, Cambridge, United Kingdom, 1989.

5 C. Li, Pillararene-based supramolecular polymers: from molecular recognition to polymeric aggregates, Chem. Commun., 2014, 50, 12420.

6 J. N. Kim and K. Y. Lee, Synthesis of cyclic compounds from the Baylis-Hillman adducts, Curr. Org. Chem., 2002, 6, 627.

7 Ś. W. liwa and T. Zujewska, Interlocked molecules containing quaternary azaaromatic moieties, Heterocycles, 2005, 65, 1713.

8 G. J. Bodwell and P. R. Nandaluru, Olefination reactions in the synthesis of cyclophanes, Isr. J. Chem., 2012, 52, 105.

9 Y. Okada and J. Nishimura, The design of cone-fixed calix [4] arene analogs by taking syn-[2.n]metacyclophanes as a building block, J. Inclusion Phenom. Mol. Recognit. Chem., 1994, 19, 41.

10 M. H. Schwartz, Charge-transfer interactions in cyclophanes, J. Inclusion Phenom. Mol. Recognit. Chem., 1990, 9, 1.

11 M. Ángeles Herranz, J. A. Rivera, R. J. Alvarado, N. Martn, C. Thilgen, F. Diederich and L. Echegoyen, Chemical retrocyclopropanation reactions in methanofullerenes: effect of the 18-crown-6 moiety, J. Supramol. Chem., 2001, 1, 299.

12 T. Gulder and P. S. Baran, Strained cyclophane natural products: macrocyclization at its limits, Nat. Prod. Rep., 2012, 29, 899.

13 M. J. McGlinchey and S. Milosevic, From [10] paracyclophane to ferrocenophanones, Isr. J. Chem., 2012, 52, 30 .

14 D. Ramaiah, P. P. Neelakandan, A. K. Nair and R. R. Avirah, Functional cyclophanes: promising hosts for optical biomolecular recognition, Chem. Soc. Rev., 2010, 39, 4158.

15 T. Gaich and P. S. Baran, Aiming for the ideal synthesis, J. Org. Chem., 2010, 75, 4657.

16 R.-Y. Tang, G. Li and J.-Q. Yu, Conformation-induced remote meta-C-H activation of amines, Nature, 2014, 507, 215.

17 S. R. Naini, S. Ranganathan, J. S. Yadav, K. V. S. Ramakrishna, G. Gayatri, G. N. Sastry, K. B. Roy and N. Shamala, The exploration of Kemp's triacid (KTA) as the core for the synthesis of 3-fold symmetric 23cyclophane, 22-cyclophane and novel linker directed designs, RSC Adv., 2014, 4, 5322.

18 M. Juriček, N. L. Strutt, J. C. Barnes, A. M. Butterfield, E. J. Dale, K. K. Baldridge, F. Stoddart and J. S. Siegel,
Induced-fit catalysis of corannulene bowl-to-bowl inversion, Nat. Chem., 2014, 6, 222.

19 S. Gago, J. González, S. Blasco, A. J. Parola, M. T. Albelda, E. Garcia-España and F. Pina, Protonation, coordination chemistry, cyanometallate "supercomplex" formation and fluorescence chemosensing properties of a bis(2,2'bipyridino)cyclophane receptor, Dalton Trans., 2014, 43, 2437.

20 M. Wang, Clicking cyclophane to boron doped diamond surfaces, Chin. Sci. Bull., 2013, 58, 2898.

21 P. Rajakumar, R. Padmanabhan and N. Rajesh, Synthesis, study on anti-arthritic, anti-inflammatory activity and toxicity of some novel bis-oxy cyclophane diamides, Bioorg. Med. Chem. Lett., 2012, 22, 3770.

22 K. Kanda, R. Hamanaka, K. Endo and T. Shibata, Asymmetric ortho-lithiation of $1, n$-dioxa[n]paracyclophane derivatives for the generation of planar chirality, Tetrahedron, 2012, 68, 1407.

23 O. Hayashida and K. Ichimura, Synthesis and characterization of reduction-responsive cyclophane dimer based on disulfide linkage, Chem. Lett., 2012, 41, 1650.

24 R. J. Vermeij, D. O. Miller, L. N. Dawe, I. Aprahamian, T. Sheradsky, M. Rabinovitz and G. J. Bodwell, Mixed [2.2] cyclophanes of pyrene and benzene, Aust. J. Chem., 2010, 63, 1703.

25 G. J. Bodwell, R. Frim, H. Hopf and M. Rabinovitz, Cyclophanes, XXXVIII. [2]metacyclo[2]indenophanes: synthesis, anions and iron complexes, Chem. Ber., 1993, 126, 167.

26 V. A. D, yakonov, O. A. Trapeznikova, A. de Meijere and U. M. Dzhemilev, Metal complex catalysis in the synthesis of spirocarbocycles, Chem. Rev., 2014, 114, 5775.

27 S. Sankararaman, M. Srinivasan, V. Narayanan and B. Varghese, Synthesis of cyclophanes bearing 1,4dioxabut-2-yne and 1,6-dioxahexa-2,4-diyne bridges and nanoscale cavities, Indian J. Chem., Sect. B: Org. Chem. Incl. Med. Chem., 2004, 43, 1499.

28 Y. Yang, M. R. Mannion, L. N. Dawe, C. M. Kraml, R. A. Pascal Jr and G. J. Bodwell, Synthesis, crystal structure, and resolution of $[10](1,6)$ pyrenophane: an inherently chiral [N]cyclophane, J. Org. Chem., 2012, 77, 57.

29 G. J. Bodwell, D. O. Miller and R. J. Vermeij, Nonplanar aromatic compounds. 6. [2] paracyclo[2](2,7)pyrenophane. A novel strained cyclophane and a first step on the road to a "Vögtle" belt, Org. Lett., 2001, 3, 2093.

30 G. J. Bodwell, T. J. Houghton and D. Miller, Synthesis, structure and AM1 conformational study of 1,12-dioxa2,11-dioxo[3.3] orthocyclophane, Tetrahedron Lett., 1997, 38, 1469.

31 G. A. Boyle, T. Govender, H. G. Kruger and G. E. M. Maguire, Synthesis of novel 3-hydroxy-3-pyridylcamphor derivatives, Tetrahedron: Asymmetry, 2004, 15, 3775.

32 P. R. Ashton, V. Balzani, A. Credi, O. Kocian, D. Pasini, L. Prodi, N. Spencer, J. F. Stoddart, M. S. Tolley, M. Venturi, A. J. P. White and D. J. Williams, Cyclophanes and [2]catenanes as ligands for transition metal complexes: synthesis, structure, absorption spectra, and 
excited state and electrochemical properties, Chem.-Eur. J., 1998, 4, 590.

33 J. B. Bremner, P. A. Keller, S. G. Pyne, A. D. Robertson, B. W. Skelton, A. H. White and H. M. Witchard, The synthesis of new dibenzothiophene amino acid and cyclophane derivatives, Aust. J. Chem., 2000, 53, 535.

34 M. V. Baker, D. H. Brown, R. A. Haque, B. W. Skelton and A. H. White, A new binding geometry for an ortho-xylylenelinked bis(NHC)cyclophane: a ruthenium(II) complex with a chelating $\left(\eta^{1}-\mathrm{NHC}\right)_{2}: \eta^{6}$-arene ligand, Dalton Trans., 2010, 39,70 .

35 J. R. Davy and J. A. Reiss, Cyclophanes. IV. Synthetic approaches to cyclophane dienes. The preparation of $[2,2](2,7)$ naphthalenophane-1,11-diene, Aust. J. Chem., 1976, 29, 163.

36 C. Davies, L. Ren, R. Gustafson, T. Buthelezi, R. A. Bartsch and M. Surowiec, Molecular association of benzene with a new cyclophane receptor, J. Inclusion Phenom. Macrocyclic Chem., 2008, 61, 347.

37 R. A. Bartsch, P. Kus, N. K. Dalley and X. Kou, A novel cyclophane-anthracene complex, Tetrahedron Lett., 2002, 43, 5017.

38 R. T. Swann and V. Boekelheide, Multilayered iron complexes of metacyclophanes, J. Organomet. Chem., 1982, 231, 143.

39 F. Gerson, J. Lopez and V. Boekelheide, The radical anion of [24](1,2,4,5)cyclophane, J. Chem. Soc., Perkin Trans. 2, 1981, 1298.

40 Y. Morisaki, R. Hifumi, L. Lin, K. Inoshita and Y. Chujo, Practical optical resolution of planar chiral pseudo-orthodisubstituted [2.2]paracyclophane, Chem. Lett., 2012, 41, 990.

41 Y. Morisaki and Y. Chujo, Synthesis of novel alternating $\pi$ conjugated copolymers having [2.2]paracyclophane and fluorene units in the main chain leading to the blue lightemitting materials, Chem. Lett., 2002, 31, 194.

42 H. Takemura, S. Nakata, A. Inoue and A. Mishima, Synthesis of a hexacationic cyclophane and formation of EDA-type host-guest complexes, J. Inclusion Phenom. Macrocyclic Chem., 2013, 77, 483.

43 J. C. Barnes, M. Juriček, N. L. Strutt, M. Frasconi, S. Sampath, M. A. Giesener, P. L. McGrier, C. J. Bruns, C. L. Stern, A. A. Sarjeant and J. F. Stoddart, A polycyclic aromatic hydrocarbon scavenger, J. Am. Chem. Soc., 2013, 135, 183.

44 P. Wald and H.-J. Schneider, Reinvestigation of supramolecular complexes with cyclophanes of the Stetter and Koga type: agreement and disagreement with solid-state structures, Eur. J. Org. Chem., 2009, 3450.

45 H. Takemura, [1n]Paracyclophanes, Curr. Org. Chem., 2009, 13, 1633.

46 B. Masci, S. Pasquale and P. Thuéry, Supramolecular control of a fast and reversible Diels-Alder reaction, Org. Lett., 2008, 10, 4835 .

47 A. Schmitt, O. Perraud, E. Payet, B. Chatelet, B. Bousquet, M. Valls, D. Padula, L. Di Bari, J.-P. Dutasta and A. Martinez, Improved hemicryptophane hosts for the stereoselective recognition of glucopyranosides, $\mathrm{Org}$. Biomol. Chem., 2014, 12, 4211.

48 H. Abe, K. Ohtani, D. Suzuki, Y. Chida, Y. Shimada, S. Matsumoto and M. Inouye, Pyridine-acetylene macrocycles: $\pi$-stacking self-assemblies enhanced by intermolecular dipole-dipole interaction, Org. Lett., 2014, 16, 828.

49 M. Juriček, J. C. Barnes, E. J. Dale, W.-G. Liu, N. L. Strutt, C. J. Bruns, N. A. Vermeulen, K. C. Ghooray, A. A. Sarjeant, C. L. Stern, Y. Y. Botros, W. A. Goddard and J. F. Stoddart, Interdependent modes of binding in a two-nanometer-long synthetic receptor, J. Am. Chem. Soc., 2013, 135, 12736.

50 E. Elacqua, T. Friščić and L. R. MacGillivray, Paracyclophane as a target of the organic solid state: emergent properties via supramolecular construction, Isr. J. Chem., 2012, 52, 53.

51 P. Hu, S. Yang and G. Feng, Discrimination of adenine nucleotides and pyrophosphate in water by a zinc complex of an anthracene-based cyclophane, Org. Biomol. Chem., 2014, 12, 3701.

52 C. J. Bruns, M. Frasconi, J. Iehl, K. J. Hartlieb, S. T. Schneebeli, C. Cheng, S. I. Stupp and J. F. Stoddart, Redox switchable daisy chain rotaxanes driven by radicalradical interactions, J. Am. Chem. Soc., 2014, 136, 4714.

53 E. M. Driggers, S. P. Hale, J. Lee and N. K. Terrett, The exploration of macrocycles for drug discovery-an underexploited structural class, Nat. Rev. Drug Discovery, 2008, 7, 608.

54 L. Jimenez and F. Diederich, Catalytic cyclophanes: a highly efficient model for pyruvate oxidase, Tetrahedron Lett., 1989, 30, 2759.

55 P. J. Pye, P. J. Pye, K. Rossen, R. A. Reamer, N. N. Tsou, R. P. Volante and P. J. Reider, A new planar chiral bisphosphine ligand for asymmetric catalysis: highly enantioselective hydrogenations under mild conditions, $J$. Am. Chem. Soc., 1997, 119, 6207.

56 W. F. Gorham, A new, general synthetic method for the preparation of linear poly-p-xylylenes, J. Polym. Sci., Part A: Polym. Chem., 1966, 4, 3027.

57 C.-Y. Yu and M. L. Turner, Soluble poly(pphenylenevinylenes) through ring-opening metathesis polymerization, Angew. Chem., Int. Ed., 2006, 45, 7797.

58 J. Gross, G. Harder, A. Siepen, J. Harren, F. Vögtle, H. Stephan, K. Gloe, B. Ahlers, K. Cammann and K. Rissanen, Concave hydrocarbons, Chem.-Eur. J., 1996, 2, 1585.

59 K. Cammann, Das arbeiten mit ionenselektiven elektroden, Springer, 1996.

60 S. Kotha and M. K. Dipak, Strategies and tactics in olefin metathesis, Tetrahedron, 2012, 68, 397.

61 D. D. Ridley, E. Ritchie and W. C. Taylor, Chemical studies of the proteaceae. IV. The structures of the major phenols of grevillea striata; a group of novel cyclophanes, Aust. J. Chem., 1970, 23, 147.

62 D. J. Newman, G. M. Cragg and K. M. Snader, The influence of natural products upon drug discovery, Nat. Prod. Rep., 2000, 17, 215. 
63 Y. Vida and E. Perez-Inestrosa, Cyclophane size drives the photochemical behaviour of benzophenone, Photochem. Photobiol. Sci., 2012, 11, 1645.

64 M. J. Cloninger and H. W. Whitlock, A synthetic receptor which uses multiple edge-face interactions to bind aromatic guests, J. Org. Chem., 1998, 63, 6153.

65 S. Kotha and G. T. Waghule, New approach to cyclophanes containing ethyleneoxy bridge by Glaser-Eglinton coupling, Heterocycles, 2015, 90, 1289.

66 J. Altmann, C. Jandl and A. Pöthig, Introducing a pyrazole/ imidazole based hybrid cyclophane: a hydrogen bond sensor and binucleating ligand precursor, RSC Adv., 2015, 44, 11278.

67 Z. Rafiee Samani, A. M. Mehranpour and A. Hasaninejad, Preparation of 2,5-disubstituted pyrimidines from vinamidinium salts and synthesis of novel disulfane derivatives, J. Heterocycl. Chem., 2020, 57, 2150.

68 Z. Rafiee Samani and A. M. Mehranpour, Synthesis of novel 5-substituted isophthalates from vinamidinium salts, Tetrahedron Lett., 2019, 60, 151002.

69 E. Bahman Jahromi and A. M. Mehranpour, A novel synthesis of new 1,8-naphthyridine derivatives using the reaction of vinamidinium salts with 2,6-diaminopyridine, Org. Prep. Proced. Int., 2016, 48, 468.

70 E. Bahman Jahromi, A. M. Mehranpour and N. Nowrouzi, Facile synthesis of novel 3-substituted pyrido[1,2-a] pyrimidinium salts using vinamidinium salts, Synth. Commun., 2016, 46, 1833.

71 A. M. Mehranpour, S. Hashemnia and J. Ameri Rad, Synthesis of new metal-free 1,4,8,11-tetraaza[14]annulene derivatives using 2-heteroaryl-substituted trimethinium salts, J. Heterocycl. Chem., 2013, 50, 821.

72 A. M. Mehranpour, S. Hashemnia and R. Maghamifar, Synthesis and characterization of new $\gamma$-substituted pentamethine cyanine dyes, Synth. Commun., 2010, 40, 3594.

73 A. M. Mehranpour, S. Hashemnia and F. Azamifar, Synthesis of new malonaldehyde derivatives using 2-heteroarylsubstituted trimethinium salts, Tetrahedron Lett., 2013, 54, 321.

74 A. M. Mehranpour and M. Zahiri, Synthesis and characterization of new benzimidazole derivatives using 2substituted 1,3-bis(dimethylamino)-trimethinium salts, Tetrahedron Lett., 2014, 55, 3969.

75 A. M. Mehranpour, S. Hashemnia and E. Bashiri, Synthesis of new dibenzo-tetraaza and dibenzo-dioxadiaza[14] annulene derivatives using 3-bromo-substituted vinamidinium salt, Synth. Commun., 2013, 43, 1931.

76 A. M. Mehranpour, Synthesis of new derivatives of 1,5,9,13tetraaza[16]annulene using 2-substituted vinamidinium salts, Tetrahedron Lett., 2014, 55, 5229. 